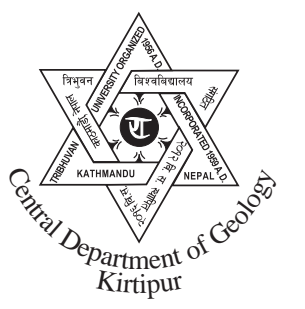

Bulletin of the Department of Geology

Bulletin of the Department of Geology, Tribhuvan University, Kathmandu, Nepal, Vol. 10, 2007, pp. 21-32

\title{
Environmental status of Manahara River, Kathmandu, Nepal
}

\author{
*Ramita Bajracharya and Naresh Kazi Tamrakar \\ Central Department of Geology, Tribhuvan University, Kirtipur, Kathmandu, Nepal
}

\begin{abstract}
The Manahara River located in northeast part of the Kathmandu Valley has been disturbed for last one decade by several anthropogenic activities and natural causes thereby deteriorating its recreational functions and stream habitat. To obtain an existing environmental condition and disturbances of the river, the river was surveyed for its habitat, pollution level and surface water quality. Among the five representative segments of the river, the downstream segment (Sano Thimi) was scored into intermediate category showing more pollution and environmental deterioration compared to the upstream segments. Turbidity, electrical conductivity, chemical oxygen demand, biological oxygen demand and ammonia increase, whereas dissolved oxygen decreases from upstream to downstream with exponential functions. Aquatic lives like Garra sp. (Buduna), Schizothorax sp. (Asala), Channa sp. (Hiele) and Heteropneustes sp. (Singe) were observed except in downstream of the Jadibuti Bridge situated downstream from Sano Thimi stretch. Fish species were rare from the Jadibuti area most probably due to reduced dissoved oxygen ( $5 \mathrm{mg} / \mathrm{l})$. Coliform bacteria ranged from 3000 to 4000 in the Manahara River showing high amount of bacterial contamination. Major disturbances, which affect river habitat and surface water quality of the Manahara River were destruction of riparian buffer zones, excavation excessive amount of sand from the river, encroachment of floodplains and bars, solid waste and sewer effluent, and tendency of landuse change. To retard environmental degradation of the Manahara River from the human-induced activities, local government needs to take immediate action.
\end{abstract}

\section{INTRODUCTION}

Rivers are natural resources which have ecological and recreational functions. People mostly depend on rivers for agricultural and domestic purposes. Many temples and crematories located around the river have increased cultural values of the rivers. But with rapid growing population and urbanization, different activities like unplanned building and encroachment, clearing of riparian vegetation along the river banks, disposal of waste materials in river and unwise mining of construction materials from the rivers are commonly observed in rivers of the Kathmandu Valley. Human as well as natural phenomena are responsible for bringing disturbances in the river system. The Bishnumati River, one of the biggest tributaries of the Bagmati River, is suffering from these types of activities (Tamrakar 2004a and b).

*Corresponding author:

E-mail address: bajrarami@yahoo.com
The Manahara River as a whole has been in deteriorating condition from last one decade. Growing number of population and shelters, and building of structures and factories on the river banks are probably major causes for environmental deterioration (reduction of stream bank stability, cultural, ecological and recreational functions and surface water quality of rivers). Some of the major disturbances such as landuse change, bank erosion, scoring, encroachment, dilution of riparian vegetation, contamination by effluents and solid waste and shifting of the river channel are quite evident along the Manahara River. Due to lack of awareness among people and concerned authorities, such disturbances are unmanageable at present. If the disturbances in the river continue in the current trend, they will aggravate system instability and will bring unrecoverable deterioration to the river environment. Therefore, it is important to identify present environmental condition and major disturbances to rehabilitate the river in the future 
because many people depend on the water of the Manahara River. UNESCO world heritage site, Changunarayan Temple and several other places such as International Airport, Sali Nadi Temple and Nilbarahi Temple are located around this river. Therefore, this paper aims in identifying environmental condition of the river and potential disturbing factors.

\section{MANAHARA RIVER BASIN}

The Manahara River is located in the northeast of the Kathmandu Valley (Fig. 1). It is elongated in shape having $28 \mathrm{~km}$ length from NE to SW covering $83 \mathrm{sq} . \mathrm{km}$ of area. This river is straight and narrow in upstream stretch and is meandered and wide in downstream stretch. The northern and eastern catchments, composed of gneiss, granite, quartzite, metasandstone, phyllite and schist possess fine drainage texture, high relative relief and high drainage frequency. The western catchment, composed of soft fluvio-lacustrine deposits, possesses coarse drainage texture, low relative relief and low dranage frequency (Bajracharya 2006).

The maximum average monthly rainfall received was $567 \mathrm{~mm}$ in July and minimum was nil in November (Sankhu Station) during 1980-2004 (DHM 2004). The total monsoon rainfall (1980-2004) is slowly increasing. Generally, the Manahara River Basin is presently covered by cultivated, settlement and forest lands. Cultivation and settlement areas have been increasing against forest area. About 77\% of landscape were occupied by cultivation, $17 \%$ by forest and $6 \%$ by urban areas in 2002 (Shrestha 2007).

\section{FLUVIAL GEOMORPHOLOGY}

The Manahara River is a perennial stream fed by storm flow and spring. The mainstem of the river is a fifth order stream and it's major tributaries such as the Sali Nadi River, the Ghatte Khola and the Mahadev Khola are forth order streams (Fig. 2). The fifth order stream extends for $19 \mathrm{~km}$ showing highly meandering pattern. The lowest stretch (Sano Thimi) of this mainstem shows entrenched nature (Entrenchment ratio, $\mathrm{ER}=1.39)$ with high bank height ratio (BHR $=1.63)$ and gentle slope $(0.0235 \mathrm{~m} / \mathrm{m})$. River crosssectional area, discharge and velocity are highest. Point bar, side bar and point bar with few mid bar

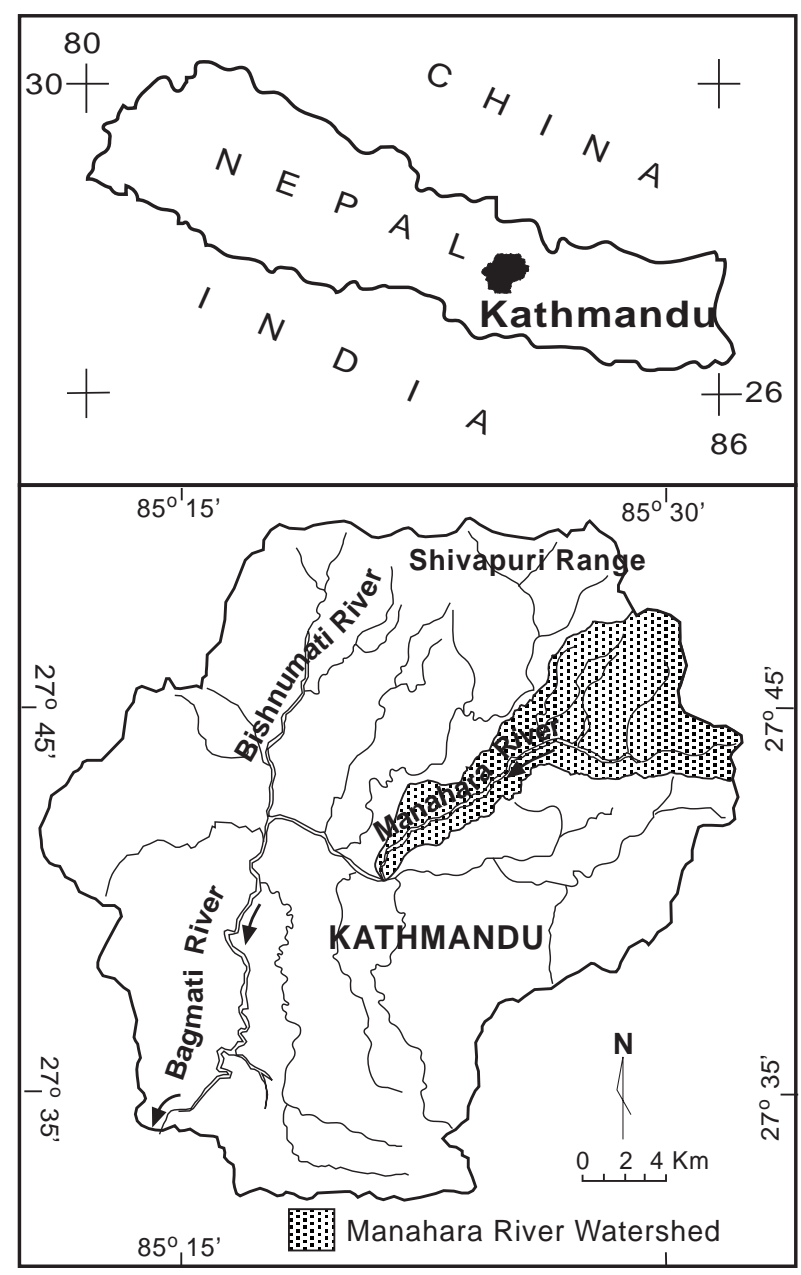

Fig. 1 Location map of study area

are characteristics of depositional pattern. Pebbles and sand with silt are main dominated channel materials.

The middle segment (Mulpani) is highly sinuous (1.81) with less entrenchement ratio (12). The material is composed of sandy pebble. Large point bar, side bar and mid bar characterize depositional pattern. Very gentle slope $(0.0056 \mathrm{~m} / \mathrm{m})$, high width/depth ratio (70) and low BHR (1.3) indicates flooding during high rainfall and channel shifting.

The upper stretch (Kurthali) also shows highly sinuous (1.5) pattern and less entrenched nature (7.71). River channel has alternating riffles and pools, and has very gentle slope $(0.011 \mathrm{~m} / \mathrm{m})$. Large point bar and side bar contains cobble, pebble and sand. Erosional scars and landslides are common of the river banks. 


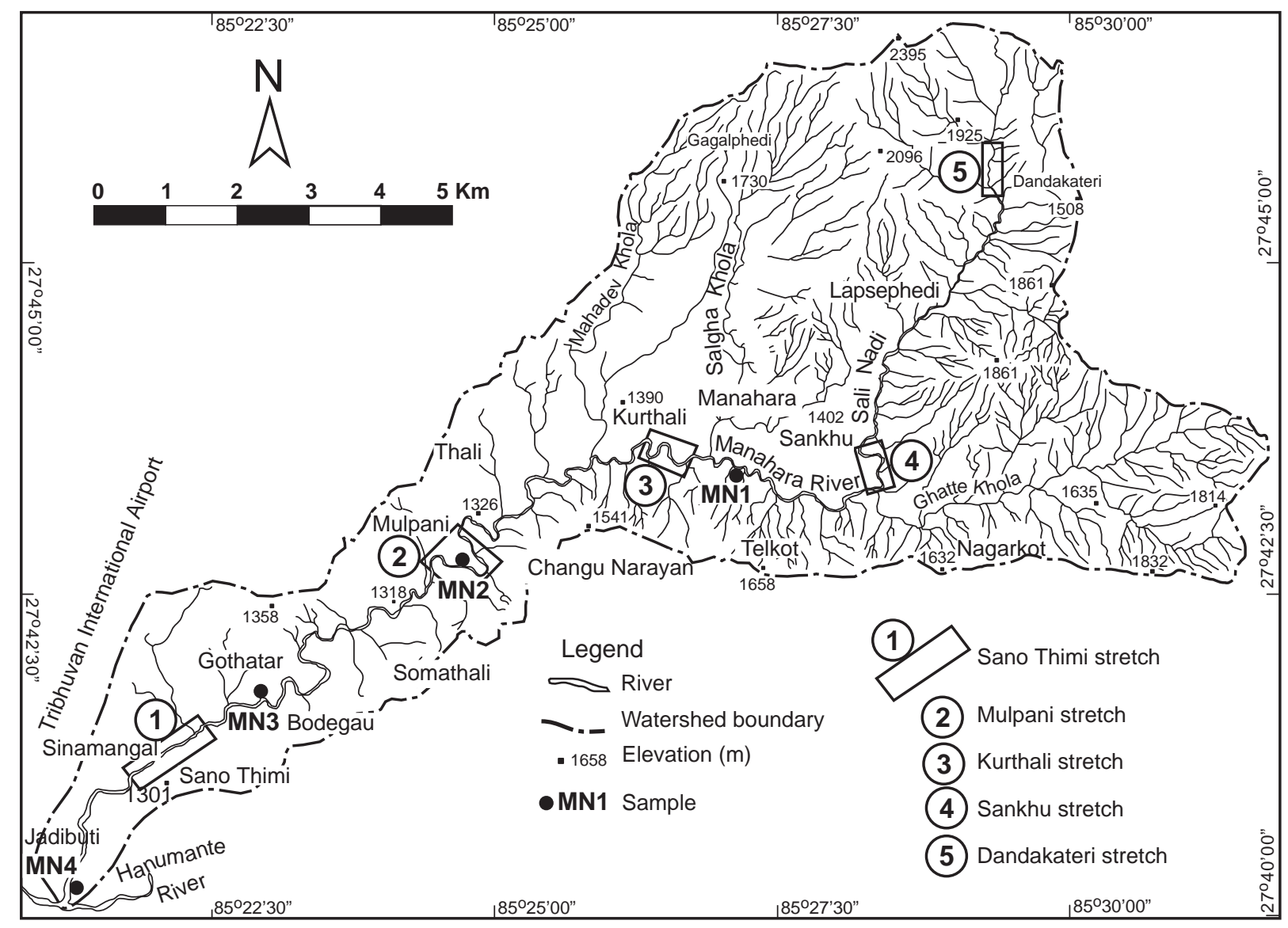

Fig. 2 Location of study stretches and water samples

The forth order stream extends for $5.9 \mathrm{~km}$ showing moderately entrenched segment $(\mathrm{ER}=1.43)$. The channel has alternating riffles and pools, and has higher slope $(0.14 \mathrm{~m} / \mathrm{m})$ compared to the fifth order stream. The river bed material consists of cobble, pebble and sand with silt. Landslide and bank erosion are common on steep slope river bank.

The third order stream stretch (Dandakateri) extends for $1.1 \mathrm{~km}$. It is straight, narrow and moderately entrenched $(E R=1.45)$ with slope of $0.07 \mathrm{~m} / \mathrm{m}$. Riverbed material is dominantly gravel (boulder, cobble and pebble) and minorly sand.

\section{METHODS}

River habitat assessment, pollution assessment and river water quality assessment were used to evaluate stream habitat condition, riparian vegetation and water quality condition of the river. Four locations from each of the five stretches were measured for longitudinal profile, parameters of water quality and riparian vegetation.

\section{River habitat assessment}

River habitat assessment was made in three parts according to the procedure of Texas Natural Resource Conservation, TNRCC (2001). In first part, three attributes, i. e. primary, secondary and tertiary were measured during field survey (Table 1). Primary data included (a) habitat type, (b) number of riffles, (c) dominant substrate type, (d) percent gravel and (e) instream cover type, which were used for evaluating the shelter and food quality for aquatic organisms. Secondary attributes focused the structures of the stream channel and included (a) channel flow status, (b) stream width and (c) stream depth. The tertiary atributes included data for (a) riparian buffer zone, (b) aesthetics of reach, (c) bank angle, (d) tree canopy 
Table 1: Summary of the river habitat assessment of the Manahara River

\begin{tabular}{|c|c|c|c|c|c|}
\hline \multirow[b]{2}{*}{ Parameters } & \multicolumn{3}{|c|}{ Segments } & \multirow[b]{2}{*}{ Sankhu } & \multirow[b]{2}{*}{ Dandakateri } \\
\hline & Sano Thimi & Mulpani & Kurthali & & \\
\hline Stream order & 5 th & 5 th & 5 th & 4th & $3 r d$ \\
\hline Streambed slope $(\mathrm{m} / \mathrm{m})$ & 0.02 & 0.0056 & 0.011 & 0.014 & 0.07 \\
\hline Length of stream evaluated (m) & 500 & 760 & 550 & 400 & 160 \\
\hline No. of lateral transect made & 4 & 4 & 4 & 4 & 4 \\
\hline \multicolumn{6}{|l|}{ Primary attributes } \\
\hline Total number of riffle & 4 & 5 & 5 & 4 & 2 \\
\hline Dominant substrate type & $\begin{array}{l}\text { Coarse sand } \\
\text { with pebble }\end{array}$ & $\begin{array}{l}\text { Pebbly } \\
\text { sand }\end{array}$ & $\begin{array}{l}\text { Sand with } \\
\text { cobble }\end{array}$ & Cobble & Boulder \\
\hline Average $\%$ of substrate gravel & 29 & 37 & 50 & 60 & 50 \\
\hline Average $\%$ of instream cover & 24 & 31 & 36 & 47 & 50 \\
\hline \multicolumn{6}{|l|}{ Secondary attributes } \\
\hline Average stream width (m) & 17.40 & 17.50 & 15.20 & 7.00 & 4.70 \\
\hline Average stream depth (m) & 0.55 & 0.64 & 0.68 & 0.35 & 0.54 \\
\hline Channel flow status & Moderate & Moderate & Moderate & Low & Low \\
\hline Maximum pool width (m) & 0.54 & 0.80 & 0.80 & 0.48 & 0.80 \\
\hline Average stream bank slope (degree) & 46 & 29 & 33 & 51 & 35 \\
\hline \multicolumn{6}{|l|}{ Tertiary attributes } \\
\hline $\begin{array}{l}\text { Average width of buffer vegetation }(\mathrm{m}) \\
\text { Average riparian vegetation }(\%) \text { by }\end{array}$ & 5 & 6 & 10 & 9 & 23 \\
\hline Tree & 0 & 0 & 3 & 12 & 43 \\
\hline Shrub & 12 & 6 & 9 & 11 & 10 \\
\hline Grass and forbe & 8 & 9 & 15 & 14 & 13 \\
\hline Cultivated land & 78 & 83 & 71 & 63 & 34 \\
\hline Other & 2 & 2 & 2 & 0 & 0 \\
\hline Average percent tree canopy & 0 & 0 & 0 & 4 & 77 \\
\hline Overall aesthetic appraisal & Common & Natural & Natural & Natural & Wilderness \\
\hline
\end{tabular}

and (e) width of natural buffer vegetation. These recorded data were summarised in second part. According to these summarized data, the habitat quality index of each segment was scored and calculated in the third part. The scored data were then categorised as exceptional (26-31), high (20-25), intermediate $(14-19)$ and limited $(<13)$ for stream habitat.

\section{Pollution assessment}

Acidity and alkalinity $(\mathrm{pH})$, clarity of water, temperature of water, stream flow rate, life in stream, electrical conductivity (EC) and resistivity were measured for evaluating pollution levels in the existing stretches. Clarity of water is the indication of suspended particles carried out by river. The clarity was measured as the distance of visibility of an object within the water column from the observer.

\section{Stream water quality}

Stream water quality was assessed in terms of the available parameters measured by DHM (2005) in Jadibuti, the downstream locality south of Sano Thimi stretch, for several years and from the data of four different sites in the Manahara River (Fig. 2) measured by Nepal (2007). The parameters consisted of color, turbidity, temperature, $\mathrm{pH}$, electrical conductivity, ammonia, ammonium, nitrite, nitrate, phosphate, chloride, dissolved oxygen (DO), chemical oxygen demand (COD), biological oxygen demand (BOD) and coliform bacteria. Spatial and temporal variation of water quality was analyzed to evaluate trends of some parameters.

\section{RESULTS}

\section{River habitat quality}

The summarised field measured data for stream bed slope, parameters of primary, secondary and tertiary attributes, and average tree canopy coverage percent are tabulated in Table 1. Using these summarized data, the different parameters were scored and calculated. The Results are indicated in Table 2.

\section{Dominant substrate type}

The stream bottom of upstream (third and forth order) segments is dominated by small boulder, cobble and pebbles (Fig. 3a and b). The substrate of 
Table 2: Scoring of the river habitat

\begin{tabular}{|c|c|c|c|c|c|c|c|c|c|c|}
\hline \multirow[b]{3}{*}{$\begin{array}{l}\text { Habitat } \\
\text { parameters }\end{array}$} & \multicolumn{10}{|c|}{ Streches } \\
\hline & \multicolumn{2}{|c|}{ Sano Thimi } & \multicolumn{2}{|l|}{ Mulpani } & \multicolumn{2}{|l|}{ Kurthali } & \multicolumn{2}{|l|}{ Sankhu } & \multicolumn{2}{|c|}{ Dandakateri } \\
\hline & $\begin{array}{l}\text { Scoring } \\
\text { categories }\end{array}$ & Score & $\begin{array}{l}\text { Scoring } \\
\text { categories }\end{array}$ & Score & $\begin{array}{l}\text { Scoring } \\
\text { categories }\end{array}$ & Score & $\begin{array}{l}\text { Scoring } \\
\text { categories }\end{array}$ & Score & $\begin{array}{l}\text { Scoring } \\
\text { categories }\end{array}$ & Score \\
\hline Instream cover & Rare & 2 & Common & 3 & Common & 3 & Common & 3 & Common & 3 \\
\hline Bottom substrate stability & $\begin{array}{l}\text { Moderately } \\
\text { unstable }\end{array}$ & 2 & $\begin{array}{l}\text { Moderately } \\
\text { stable }\end{array}$ & 3 & $\begin{array}{l}\text { Moderately } \\
\text { stable }\end{array}$ & 3 & Stable & 4 & Stable & 4 \\
\hline Number of riffle & Common & 3 & Abundant & 4 & Abundant & 4 & Common & 3 & Common & 3 \\
\hline Dimension of largest pool & Moderately & 3 & Moderately & 3 & Moderately & 3 & Small & 2 & Moderately & 3 \\
\hline Channel flow status & Moderate & 3 & Moderate & 3 & Moderate & 3 & Low & 2 & Low & 2 \\
\hline Bank stability & $\begin{array}{l}\text { Moderately } \\
\text { unstable }\end{array}$ & 1 & Stable & 3 & $\begin{array}{l}\text { Moderately } \\
\text { stable }\end{array}$ & 2 & $\begin{array}{l}\text { Moderately } \\
\text { unstable }\end{array}$ & 1 & $\begin{array}{l}\text { Moderately } \\
\text { stable }\end{array}$ & 2 \\
\hline Channel sinuosity & Moderate & 2 & High & 1 & Modrate & 1 & Moderately & 1 & Extensive & 3 \\
\hline Riparian buffer vegetation & Moderate & 1 & Moderate & 1 & Moderate & 1 & Moderate & 1 & Extensive & 3 \\
\hline $\begin{array}{l}\text { Aesthetic of reach } \\
\text { Total score }\end{array}$ & Common & $\begin{array}{r}1 \\
18\end{array}$ & Natural area & $\begin{array}{r}2 \\
25\end{array}$ & Natural area & $\begin{array}{r}2 \\
24\end{array}$ & Natural area & $\begin{array}{r}2 \\
20\end{array}$ & Wilderness & $\begin{array}{r}3 \\
24\end{array}$ \\
\hline
\end{tabular}

downstream (fifth order) segment is characterised by pebble and sand. Due to the presence of soft sediments, fifth order streams are susceptible to bank erosion and bed scouring.

\section{Riparian vegetation}

Riparian vegetation along the Manahara River is variable in width, vegetation type and distribution. Width of natural buffer vegetation in Dandakateri segment is wide $(23 \mathrm{~m})$ and dense, and dominated by trees, shrubs and grass having higher canopy compared to other segments (Fig. 3a). Sankhu segment having trees, shrubs and grass possess good riparian vegetation (Fig. 3b). In Mulpani area, trees are nearly absent, and flooplains and banks are covered with crops (Fig. 3c). The downstream of the bridge at Sano Thimi, streambanks are covered with grass and bushes (Fig. 3d). Tree cannopy is rare.

\section{Habitat quality index}

The scores for each of the stream stretches are given in Table 2. Sano Thimi stretch was scored 18. The calculated total scores of the upper four stretches are more or less equal (20-25) which shows suitable environment for aquatic lives.

\section{Degree of Pollution}

The results of pollution assessment are shown in Table 3. Surface water of upstream stretches shows slightly alkaline (7.2-7.5) with low EC (66-83) and high water clarity (9-12). The water of downstream stretches of the Manahara River near Sano Thimi is acidic (5.96) and has high EC (216) with low clarity $(5 \mathrm{~m})$ exhibiting worse condition compared to that of the upstream stretches. EC is the highest in Sano Thimi segment, almost three times greater than the EC in Sankhu stretch due to the direct contamination of sewer and solid waste to the river. The clarity decreases about 50\% compared to that of Sankhu stretch indicating turbid water in Sano Thimi stretch. Except in downstream of Jadibuti Bridge, aquatic lives such as Garra sp. (Buduna), Channa sp. (Hiele), Schizothorax sp. (Asal), and Heteropneustes sp. (Singe) are common in the river (Fig. 4).

\section{Water quality}

From the analysis of data obtained from DHM (2005) the water quality of river in Sano Thimi area is being deteriorated as the year passed. Temporal variation of chemical parameters shows fluctuating trends (Fig. 5). The value of phosphate and nitrite abruptly increase in 2004, suggesting that the increased content is related to pollution of the river with sewages, faecal and detergents which perhaps had affected oxygen concentration. The data of different water quality parameters also vary with seasons (Table 4).

The spatial variation of parameters was evaluated. Turbidity, colour, EC, $\mathrm{COD}, \mathrm{Cl}$ and $\mathrm{NH}_{3}$ tend to increase (Fig. 6), but DO tends to decrease from upstream towards downstream. DO of Sano Thimi stretch nearly equals to suggested value $(5 \mathrm{mg} / \mathrm{l})$, 

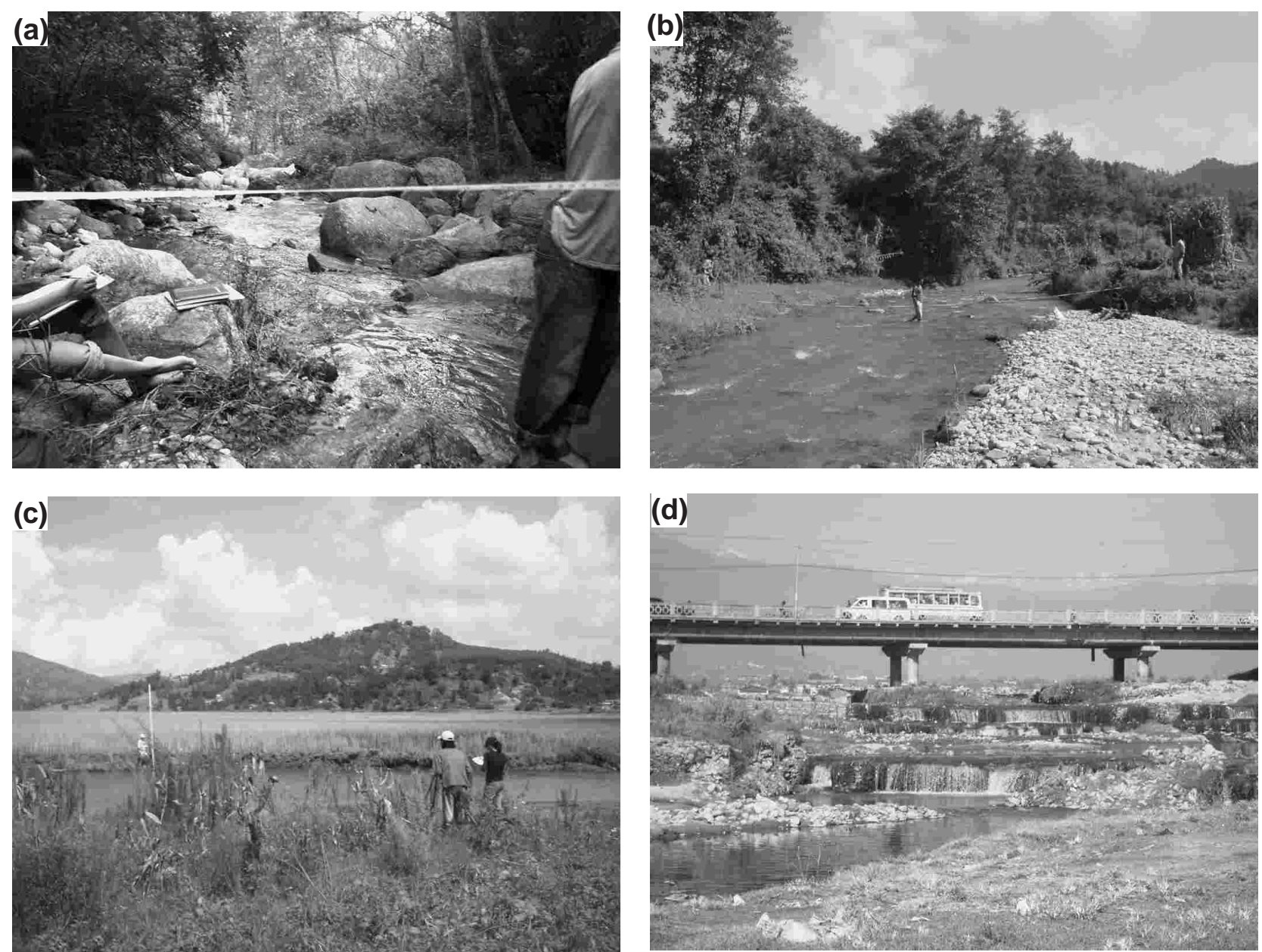

Fig. 3 Photographs showing vegetation condition and substrate material: (a) Boulder and cobble with trees in Dandakateri stretch, (b) Trees, shrubs and grass in the bank of Sankhu stretch, (c) Narrow riparian zone and cultivation in point bar at downstream of Mulpani, and (d) Poor and narrow vegetation in downstream of Sano Thimi stretch
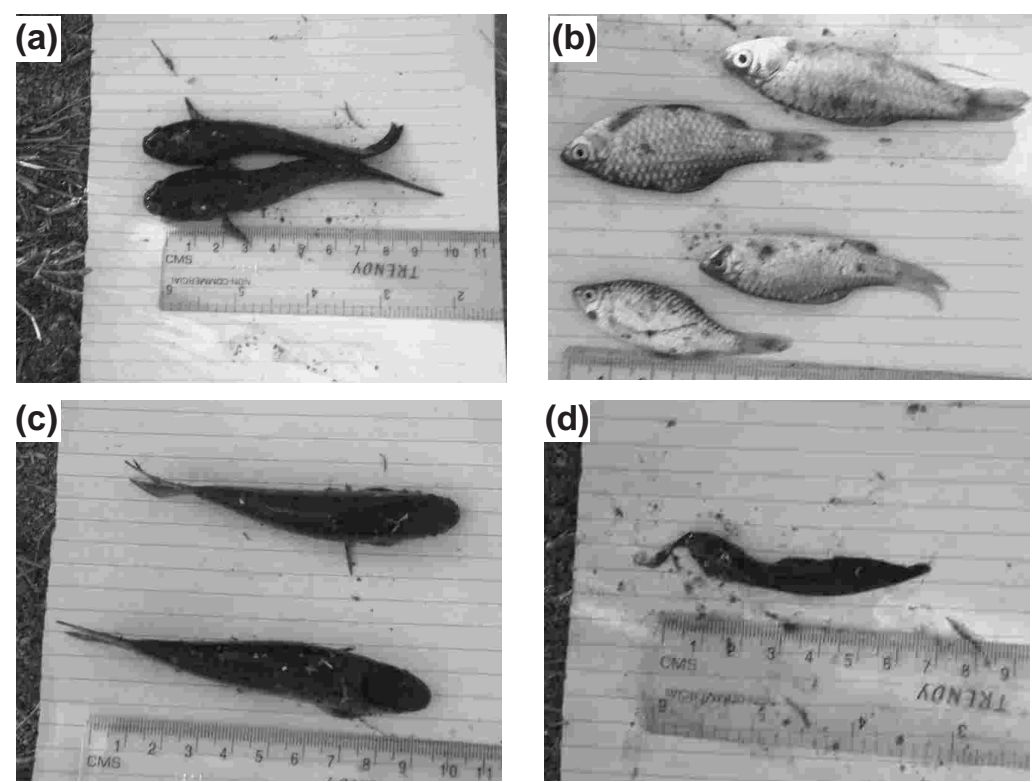

Fig. 4 Aquatic lives (fishes) found in about $100 \mathrm{~m}$ upstream of Sano Thimi stretch: (a) Garra sp. , (b) Schizothorax sp. , (c) Channa $s p$. and (d) Heteropneustes sp. 
Environmental status of Manahara River, Kathmandu, Nepal

Table 3: Results of pollution assessment

\begin{tabular}{|c|c|c|c|c|c|}
\hline \multirow{2}{*}{\multicolumn{2}{|c|}{ Parameters }} & \multicolumn{4}{|c|}{ Segments } \\
\hline & & Sano Thimi & Mulpani & Kurthali & Sankhu \\
\hline \multirow{7}{*}{$\begin{array}{l}\text { Velocity, } \mathrm{m} / \mathrm{s} \\
\text { Discharge, } \mathrm{m}^{3} / \mathrm{s} \\
\text { Clarity of water, } \mathrm{m} \\
\text { Temperature, }{ }^{\circ} \mathrm{C}\end{array}$} & & 0.37 & 0.31 & 0.25 & 0.21 \\
\hline & & 0.21 & 0.16 & 0.17 & 0.06 \\
\hline & & 5.0 & 9.0 & 10.0 & 11.5 \\
\hline & Surface & 22.5 & 22 & 22.3 & 22.6 \\
\hline & Bottom & 21.0 & 22.5 & 22.3 & 21.8 \\
\hline & Shade & 16.0 & 18 & 17.7 & 17.4 \\
\hline & Sun & 25.5 & 25 & 22.4 & 23.9 \\
\hline \multicolumn{2}{|l|}{ Stream life } & \multicolumn{4}{|c|}{ Garra sp., Channa sp. Schizothorax sp. and Heteropneustes st } \\
\hline \multirow{2}{*}{\multicolumn{2}{|c|}{$\begin{array}{l}\mathrm{pH} \\
\mathrm{EC}, \quad \mathrm{S} / \mathrm{cm} \\
\mathrm{R}, \quad \mathrm{m}\end{array}$}} & 5.96 & 7.22 & 7.50 & 7.28 \\
\hline & & $\begin{array}{l}216.0 \\
46.42\end{array}$ & $\begin{array}{r}83.6 \\
120.86\end{array}$ & $\begin{array}{r}83.4 \\
118.36\end{array}$ & $\begin{array}{r}66.7 \\
148.6\end{array}$ \\
\hline
\end{tabular}

Table 4: Water quality data after DHM (1992) and Nepal (2007)

\begin{tabular}{|c|c|c|c|c|c|c|c|c|c|c|c|c|c|c|c|c|}
\hline Location & Date & Colour & $\begin{array}{l}\text { Temp. } \\
\left({ }^{\circ} \mathrm{C}\right) \\
\end{array}$ & $\begin{array}{l}\mathrm{EC} \\
\mathrm{S} / \mathrm{cr}\end{array}$ & $\begin{array}{l}\text { Turbidity } \\
\text { m) (NTU) }\end{array}$ & $\mathrm{pH}$ & DO & $\mathrm{NH}_{3}$ & $\mathrm{NH}_{4}$ & $\mathrm{NO}_{3}$ & $\mathrm{NO}_{2}$ & $\mathrm{PO}_{4}$ & $\mathrm{Cl}$ & COD & BOD & $\begin{array}{l}\text { Coliform } \\
/ 100 \mathrm{mg}\end{array}$ \\
\hline \multirow[t]{8}{*}{${ }^{1}$ Jadibuti } & 07/12/1992 & Brown & 19 & 76 & & 7.5 & 8.5 & & 0.8 & 0.5 & 0.1 & 3.1 & 0 & & & \\
\hline & 03/12/1993 & Brown & 17.8 & 92 & & 8.3 & 8.8 & & 0.2 & 0.0 & 0.0 & 3.1 & 20.0 & & 7.8 & \\
\hline & 17/02/1994 & Brown & 19.8 & 161 & & 6.5 & 7.9 & & 0.2 & 0.0 & 0.1 & 0.0 & 5.0 & & 4.8 & \\
\hline & $16 / 02 / 1995$ & Brown & 18.1 & 100 & & 6.7 & 7.7 & & 0.4 & 0.8 & 0.2 & 10.4 & 6.7 & 4 & 7.5 & \\
\hline & $06 / 09 / 2001$ & Brown & 27.2 & 66 & & 7.0 & 6.5 & & 1.7 & 0.3 & 0.4 & 5.3 & 5.9 & & & \\
\hline & $16 / 12 / 2002$ & Grey & 17.7 & 104 & & 7.0 & 6.9 & & 0.6 & 2.2 & 1.7 & 2.54 & 3.8 & & & \\
\hline & $04 / 12 / 2003$ & Grey & 20 & 98 & & 6.5 & 12.5 & & 3.8 & 5.6 & 11.2 & 2.24 & 2.0 & & & \\
\hline & $29 / 06 / 2004$ & Brown & 27.9 & 206 & & 7.0 & 8.9 & & 0.62 & 0.0 & 12.4 & 14.2 & 35.0 & & & \\
\hline${ }^{2} \mathrm{MN} 1$ & $16 / 11 / 2005$ & 10 & 16.4 & 100 & 6.0 & 7.2 & 6.8 & 4 & & & & & 6.4 & 23 & 1.2 & 3000 \\
\hline MN2 & $16 / 11 / 2005$ & 20 & 16.4 & 110 & 7.5 & 5.6 & 6.3 & 4 & & & & & 6.6 & 33 & 4.24 & 3000 \\
\hline MN3 & $16 / 11 / 2005$ & 28 & 16.4 & 140 & 17.0 & 5.7 & 6.2 & 12 & & & & & 6.8 & 36 & 9.69 & 3000 \\
\hline MN4 & $16 / 11 / 2005$ & 30 & 16.4 & 210 & 12.0 & 5.8 & 5.2 & 11 & & & & & 12.0 & 120 & 6.06 & 4000 \\
\hline
\end{tabular}

${ }^{1} \mathrm{DHM}(2005) ;{ }^{2} \mathrm{Nepal}(2007)$

indicating more difficient condition than that in the upstream stretches. EC, turbidity, $\mathrm{Cl}$ and $\mathrm{NH}_{3}$ become double in the span of $20 \mathrm{~km}$. Contamination of fertilizer from cultivated land, effluent from sewer pipes and streambank erosion are probably the major sources for increasing the above parameters. BOD and coliform drastically increase downstream of Sano Thimi stretch.

\section{DISTURBANCES}

Both natural and human-induced factors tend to disturb river environment. Human-induced activities influence the river environment in a very short time as compared to natural factors.

\section{Natural factors}

Natural disturbances in the Manahara River are brought by neotectonic activities. Major northwestsoutheast trending lineaments for example, the Kalpu Falult, the Chandragiri Fault and the Manahara River Fault extend in the Kathmandu Valley (Bajracharya 1992; Saijo et al. 1995; Yagi et al. 2000) that upset the base level of the rivers of the northern regions in the long run. The Manahara River has incised and widen its valley against active uplift of the Changu Narayan Hills (Bajracharya 2001).

If we observe the rainfall data of 1980-2004, the total monsoon rainfall is increasing. The increase in rainfall also increases discharge of the river. The 


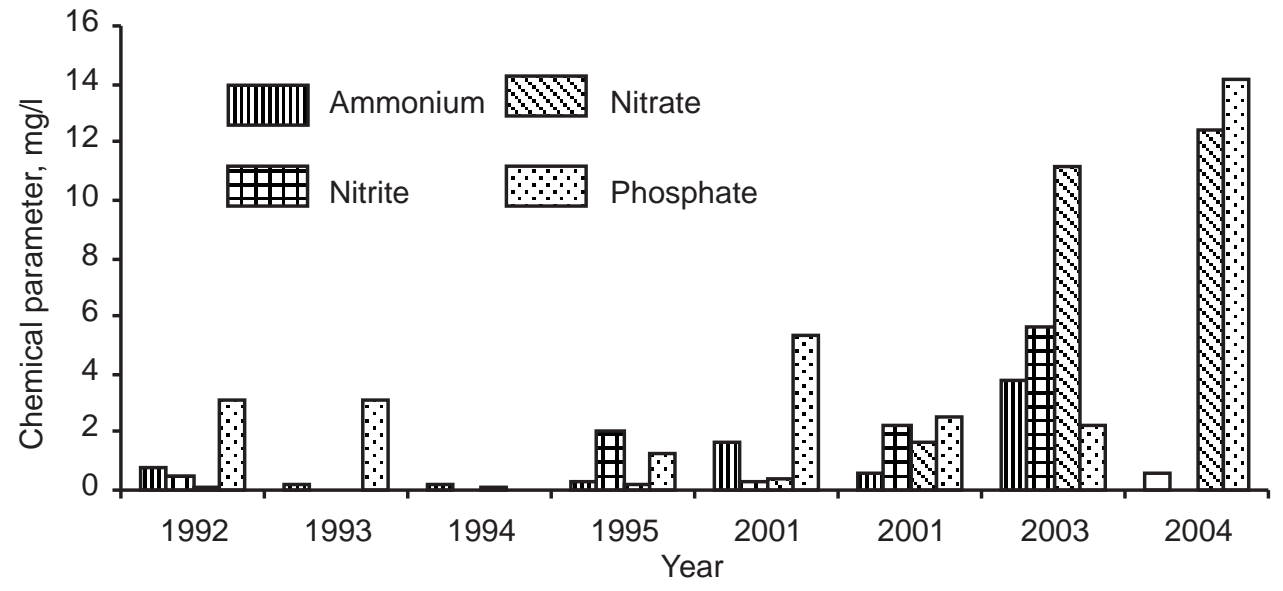

Fig. 5 Temporal variation of chemical parameters of the surface water of the Manahara River (based on DHM 2005)

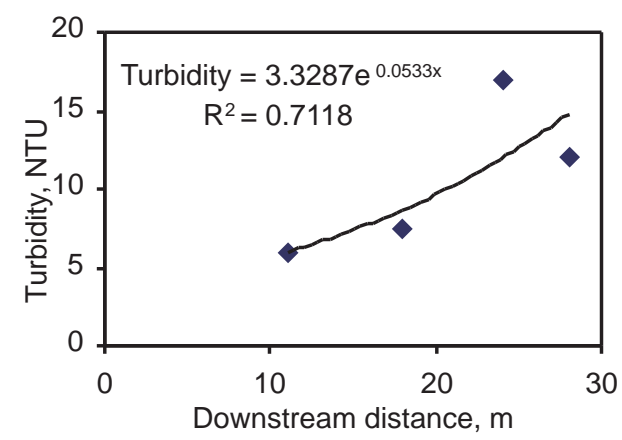

(a)

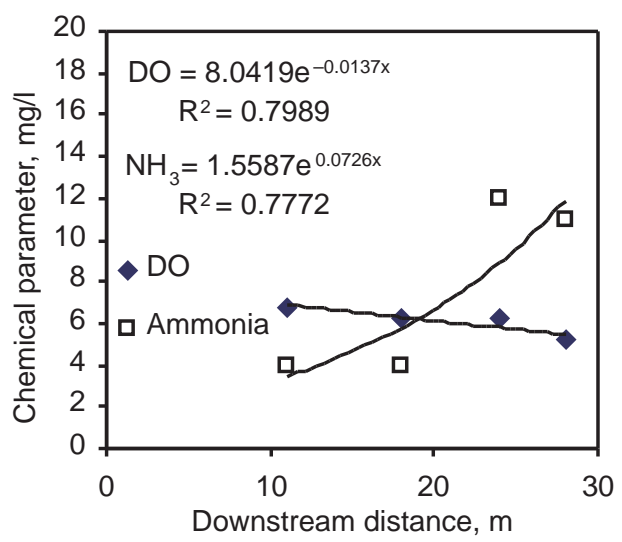

(c)

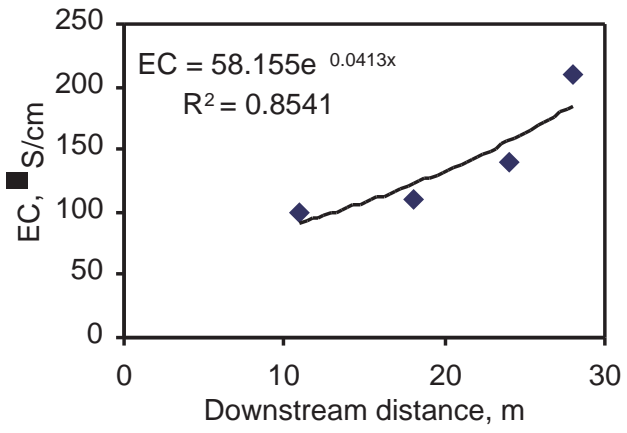

(b)

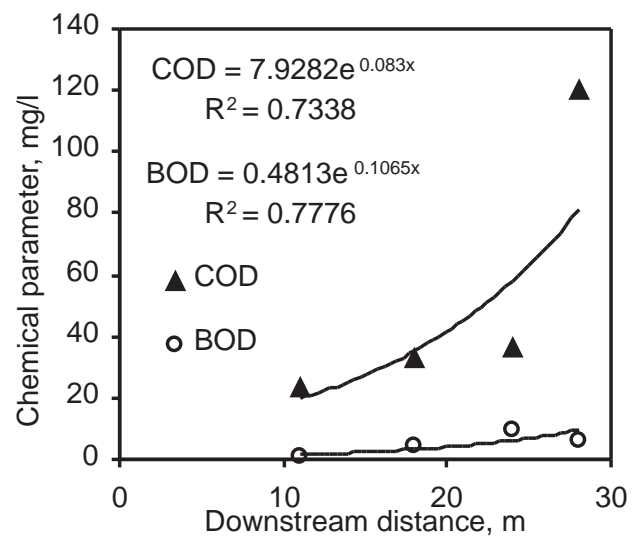

(d)

Fig. 6 Spatial variation of physical and chemical parameters of the surface water of the Manahara River (based on Nepal 2007): (a) Turbidity, (b) Electrical conductivity (EC), (c) DO and $\mathrm{NH}_{3}$, and (d) COD and BOD 
Table 5: Disturbances in the Manahara River

\begin{tabular}{|c|c|c|c|c|c|c|}
\hline Instability & Factor & Sano Thimi & Mulpani & $\begin{array}{l}\text { Segments } \\
\text { Kurthali }\end{array}$ & Sankhu & Dandakateri \\
\hline \multirow[t]{3}{*}{ Systemwide } & Upstream factor & $\begin{array}{l}\text { Sand excavation } \\
\text { Encroachment } \\
\text { Channelization }\end{array}$ & Sand excavation & $\begin{array}{l}\text { Encroachment } \\
\text { Channelization }\end{array}$ & $\begin{array}{l}\text { Encroachment } \\
\text { Channelization }\end{array}$ & \\
\hline & Downstream factor & $\begin{array}{l}\text { Knick point } \\
\text { Sand excavation }\end{array}$ & $\begin{array}{l}\text { Knick point } \\
\text { Sand excavation }\end{array}$ & Knick point & Knick point & Knick point \\
\hline & Basinwide factor & $\begin{array}{l}\text { Urbanization } \\
\text { Vegetation clearing } \\
\text { Cultivation } \\
\text { Livestock grazing }\end{array}$ & $\begin{array}{l}\text { Landuse change } \\
\text { Vegetation clearing }\end{array}$ & Landuse change & $\begin{array}{l}\text { Landuse change } \\
\text { Deforestation }\end{array}$ & $\begin{array}{l}\text { Landuse change } \\
\text { Deforestation }\end{array}$ \\
\hline Local & & $\begin{array}{l}\text { Bank erosion } \\
\text { Bank failure } \\
\text { Sand excavation } \\
\text { Encroachment } \\
\text { Destruction of } \\
\text { riparian zone }\end{array}$ & $\begin{array}{l}\text { Bank erosion } \\
\text { Bank failure } \\
\text { Sand excavation } \\
\text { Impinging flow } \\
\text { Destruction of } \\
\text { riparian zone }\end{array}$ & $\begin{array}{l}\text { Bank erosion } \\
\text { Bank failure } \\
\text { Impinging flow }\end{array}$ & $\begin{array}{l}\text { Bed scouring } \\
\text { Bank failure }\end{array}$ & $\begin{array}{l}\text { Bed scouring } \\
\text { Slope failure }\end{array}$ \\
\hline
\end{tabular}

discharge also increases with change in watershed landuse. The increased discharge will have high capacity to erode riverbanks and channel sediments.

\section{Human-induced factors}

Domestic and industrial activities related to economy and lives are more serious factors of disturbance. Recognised human-induced activities in the Manahara River are listed in Table 5 and shown in Fig. 7. These activities also influence to the systemwide and local instabilities of the river Tamrakar (2004b).

\section{Excavation of sediments}

Excessive sand excavation was observed in Mulpani area (Fig. 8a). Dwellers also excavated small amount of sand from Sano Thimi and Jadibuti areas. Excavation of excessive amount of sand from the riverbed has not only upset the balance that river tends to maintain along its course (Lane 1955), but also has deteriorated morphology and environment of the river (Tamrakar 2004a and b).

\section{Deforestation and vegetation clearing from banks}

Upstream stretches of Kurthali and the area between Dandakateri and Sankhu have problems of deforestation and rapid building of settlement areas and roads. The forest land has been converted to cultivated land and settlement areas at several localities in the Manahara River basin. Vegetation clearing from the banks of the river is commonly found throughout the river corridor, however the degree of destruction is remarkable in the river segment between Mulpani and Sano Thimi areas. Removal of vegetation from the river bank and flood plains alters hydrological and geomorphic functions of the river. This is major factor for bank failure, lateral shifting of river course, and degradation of water quality because grass and other ground cover plants that filter sediments, nutrients and pollutants from run-off water to enter the stream, and that baffle the sediment and dust have been removed.

\section{Landuse change}

Landuse change is mostly observed in watershed. Shrestha (2007) reported that $87 \%$ area of forest reduced to $17 \%, 13 \%$ of the cultivated land expanded to $77 \%$ and $0.002 \%$ urban area increased to $5 \%$ during the years 1978-2002. Landuse change is also remarkable in Sano Thimi when the landuse of areas nearby the river is considered. In this area, the agricultural land has been changed into bulid up areas quite rapidly during the last ten years.

\section{Enroachment of floodplain and channel}

Encroachment of channel and flood plain are observed in all stretches of the Manahara River. 


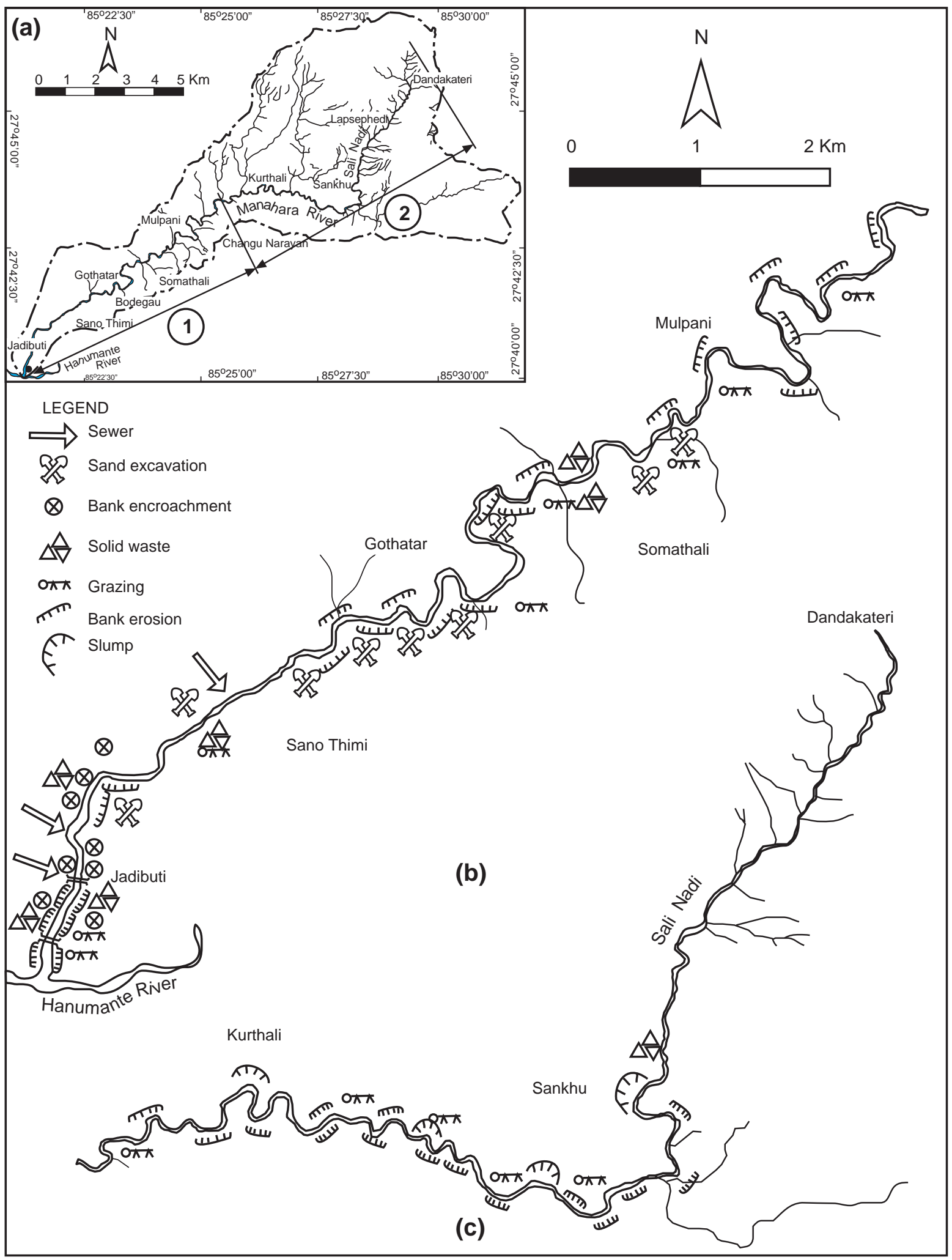

Fig. 7 Map showing disturbance along the stretches of the Manahara River: (a) index map, (b) segment 1 and indicated in the index map and (c) segment 2 

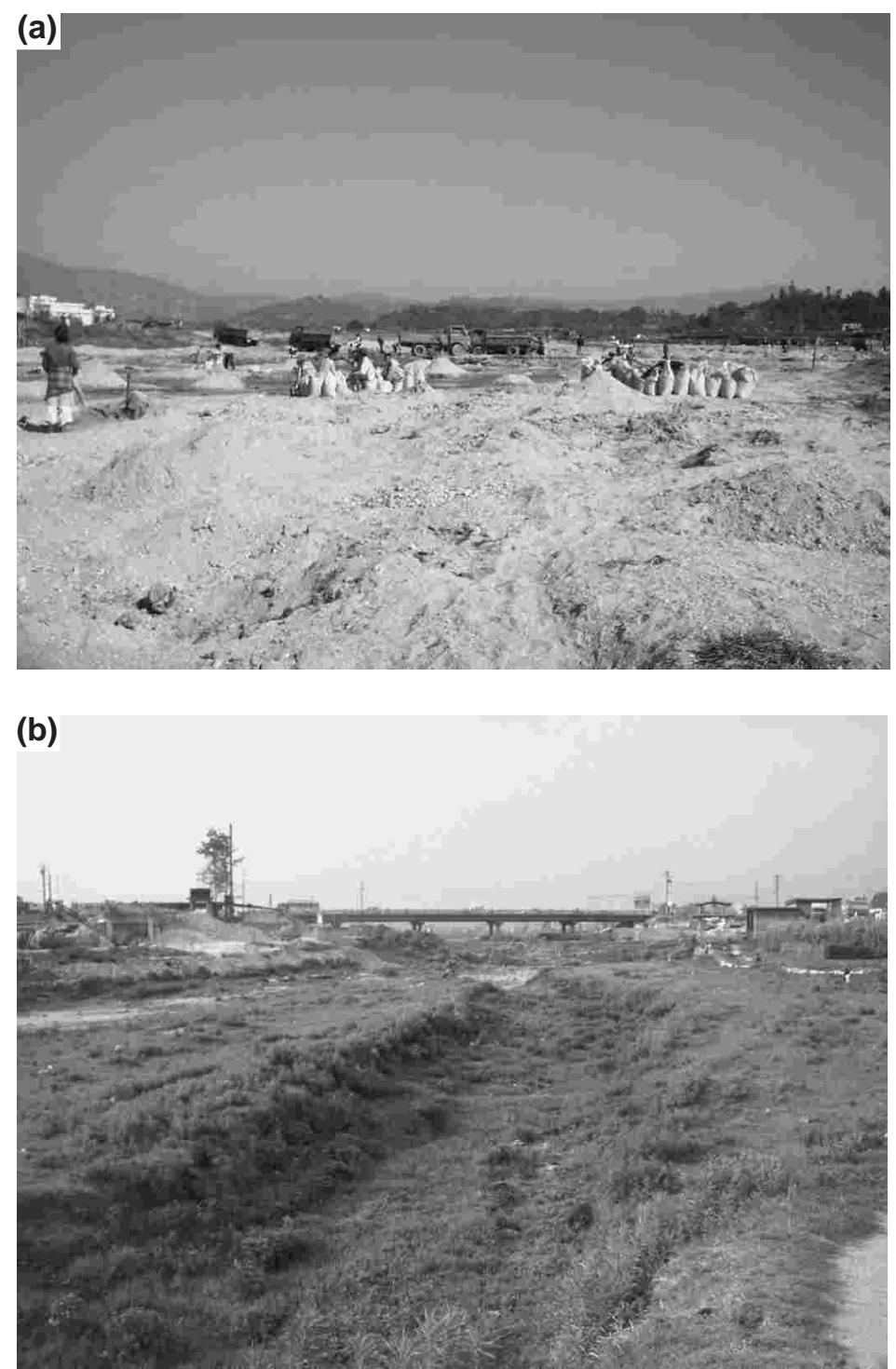

Fig. 8 Photographs indicating disturbances: (a) Sand mining near Mulpani area and (b) Bank encroachment in downstream of the Jadibuti Bridge near Sano Thimi

Except in the Sano Thimi stretch, the land is encroached at rest of the stretches for cultivation. But in downstream stretches of the Sano Thimi near Jadibuti, the channel and banks of the river have been encroached for settlement (Fig. 8b). The settlement areas, which dispose the waste, are the pollutants for the river.

\section{Solid waste and sewer disposal}

Solid waste and sewer disposing directly towards the river is pronounced in the entire stretch of the river in Sano Thimi. Town planning areas and settlement areas are the major pollutants. The sewer and solid disposal activities greatly affect water quality, cultural and social welfare, and aquatic ecosystem.

\section{Open defecation and livestock grazing}

Open defecation is common in the area between Jadibuti and Sano Thimi areas but livestock grazing was found almost in all areas of the river. They contaminate rivers by their excretory products which become source of chemicals such as ammonia, nitrate and ammonium. 
Local people use surface water of the Manahara River for taking bath, laundry and ringing vegetables. They use different soaps and detergents which also become major sources of phosphates and can decrease oxygen concentration in water.

\section{CONCLUSIONS}

River habital quality index of the Manahara River has been scored 20-25 for the stretches except for Sano Thimi which fell within intermediate level (18), showing more pollution and environmental deterioration. Dissolved oxygen is low $(5 \mathrm{mg} / \mathrm{l})$ in Sano Thimi stretch, but is still sufficient for fishes to survive. BOD, COD, EC and coliform bacteria remarkably increase in this segment. Fish species are rare in the downstream reach of the river from the Jadibuti area most probably due to reduced dissolved oxygen and increased amount of other chemical parameters.

Major disturbances, which affect river habitat and surface water quality are solid and sewer effluent, encroachment of floodplains, bars and channel, landuse change, destruction of riparian buffer zones and excavation excessive amount of sand from the river. To prevent environmental degradation of the Manahara River from the human-induced activities, local government needs to take immediate action.

\section{ACKNOWLEDGEMENTS}

Authors are thankful to the Central Department of Geology, Tribhuvan University, Nepal for providing facilities for survey. Authors thank Department of Hydrology and Meteorology and P. N. Nepal, Department of Water Supply and Sewage for providing water quality data. Authors also thank P. Shrestha and S. Shah for their assistance during field survey.

\section{REFERENCES}

Bajracharya, K.R., 2001. Geology of Bhaktapur-Nagarkot area. M. Sc. Thesis (unpublished) submitted to the Central Department of Geology, Tribhuvan University, Kathmandu, Nepal, 76p.
Bajracharya, R., 2006. Study of geoenvironmental problems of the Manohara River, Kathmandu, Nepal. Unpublished M. S. Thesis submitted to Central Department of Geology, Tribhuvan University, Kathmandu, Nepal, 132p.

Bajracharya, S.R., 1992. Fluvial system of Kathmandu valley in relation to neotectonics. Bulletin of Department of Geology, Tribhuvan University, Kathmandu, v. 2, no. 1, pp. 173-179.

DHM, 2005. Hydrological records of Nepal, Kathmandu, Department of Hydrology and Meterorology (DHM), Ministry of water resources, NG, Nepal.

Lane, E.W., 1955. The importance of fluvial morphology in hydraulic engineering. Proceeding of the American Society of Civil Engineers, v. 81, pp. 1-17. Nepal, P.N., 2007. Spatial and temporal variation of surface water quality and their contribution in environmental pollution of the major rivers in Kathmandu Valley, M. Sc. thesis (unpublished) submitted to the Central Department of Geology, 112p.

Saijo, K., Kimura, K., Dangol, G., Komatsabara, T., and Yagi, H., 1995. Active faults in southern Kathmandu basin, Central Nepal, Journal of Nepal Geological Society (Special issue), v. 11, pp. 217-224.

Shrestha, P., 2007. Streambank condition, erosion process and bank erodibility and lateral instability hazard along the Manahara River with reference to bank erosion hazard mapping. Unpublished M. Sc. thesis submitted to the Central Department of Geology, Tribhuvan University, Kathmandu, Nepal, 188p.

Tamrakar, N.K., 2004a. River degradation problems along the Bishnumati River corridor in the Kathmandu Basin, a report in http//www.human-g.com, 37p.

Tamrakar, N.K., 2004b. Disturbances and instabilities in the Bishnumati River corridor, Kathmandu basin, JUSAN, v.9, pp. Issue 16, pp. 7-18.

TNRCC, 2001. Texas guide to local floodplain management. Texas Natural Resource Conservation Commission, Austin Texas, 96p.

Yagi, H., Maemoku, H., Ohtsuki, Y., Saijo, K., and Nakata, T., 2000. Recent activities faults distributed in and around Kathmandu Valley, Lower Himalayan Zone. In: Okumura, K., et al. (eds), Active faults Research for the New Millenium. Proceeding of the Hokudan Internalational Symposium and School on Active Faulting, pp. 557-560. 